\title{
The role of biofilms in subsurface transport processes
}

\author{
P. Coombs*, D. Wagner, K. Bateman, H. Harrison, A. E. Milodowski, D. Noy \\ and J. M. West
}

British Geological Survey, Kingsley Dunham Centre, Keyworth, Nottingham, NG12 5GG, United Kingdom * Corresponding author e-mail address: pcoo@bgs.ac.uk

Words: 5623

Abbreviated title: Biofilms in subsurface transport processes

\begin{abstract}
Landfill and radioactive waste disposal risk assessments focus on contaminant transport and are principally concerned with understanding the movement of gas, water and solutes through engineered barriers and natural groundwater systems. However, microbiological activity can impact on transport processes changing the chemical and physical characteristics of the subsurface environment. Such effects are generally caused by biofilms attached to rock surfaces. This paper will present the results of an experimental study of the significance of biofilm growth on groundwater flow and the transport of contaminants in intergranular and fracture porosity flow systems.
\end{abstract}

Risk assessments for landfills and geological repositories for radioactive waste are primarily based on the precepts of contaminant transport; and are concerned with understanding the movement of gas, water and solutes through engineered barriers and natural groundwater systems, within the concept of 'Source', 'Pathway' and 'Receptor'. The emphasis on solute migration for landfill investigations is reflected in the theoretical development used during numerical simulation. However, microbes living in such environments can have an impact on transport processes (Chapelle 2000; Cunningham et al. 1997; Fredrickson et al. 1989; Keith-Loach \& Livens 2002; West \& Chilton 1997; West et al. 2006). Microbial activity in any environment is generally located on chemical or physical interfaces, usually within biofilms, and the impacts can be both physical (e.g. altering porosity) and/or chemical (e.g. changing $\mathrm{pH}$, redox conditions) and may result in intracellular or extracellular mineral formation or degradation (Beveridge et al. 1997; Ehrlich 1999; Konhauser et al. 1998; Milodowski et al. 1990; Tuck et al. 2006). Where biofilm growth in a crystalline host rock promotes mineral precipitation it can reduce water inflow and this can be a positive effect for limiting the transport of contaminants. Recent experimental work has investigated some of these chemical and physical effects in more detail in the context of the geological containment of radioactive waste. This paper will examine some of these studies and will indicate the significance of biofilms in influencing both granular and fracture flow. 


\section{Biofilms}

A biofilm is an agglomeration of microbial cells and their excreted organic and inorganic products that is attached to, or coats, mineral surfaces or other substrates (Taylor \& Jaffe 1990a). Biofilms are very common in the geosphere and biosphere, forming in diverse environments including the surfaces of human teeth (Marsh 2004), wall murals and stone monuments (Dornieden et al. 2000), stream sediments (Konhauser et al. 1998), cave and mine walls (Plate 1) and the subsurface (Tuck 2006). In such natural systems, they often comprise a mixture of interacting microbial species forming complex ecosystems. Biofilm thickness is extremely variable ranging from a single cell monolayer, to thick mucous microcolonies of microbes held together by Extracellular Polymeric Substances (EPS) (Beyenal et al. 2004; Bishop et al. 1995; Fletcher 1991; Paulsen et al. 1997; Wimpenny et al. 2000). In all environments, including the subsurface, biofilm formation is initiated by the attachment of a microbe to a solid surface. Attachment may be a reversible transitory physicochemical attraction or may become permanent if the EPS forms a strong chemical bridge to the solid surface (Dowd et al. 2000). The EPS provides a matrix for the attachment of microbial cells and influences the functioning and survival of biofilms in hostile environments by providing a microenvironment for viable microbial activity that may be very different to the ambient surroundings. Biofilm structure appears to be of three main types: planar structures; stacks of microcolonies of microbes held together by EPS; or mushroom or tulip shaped formations (Wimpenny et al. 2000; Beyenal et al. 2004). However, laboratory grown biofilms often comprise interwoven filamentous biomass with micropores of 20-200 $\mu \mathrm{m}$ diameter (Okabe et al. 1998).

The formation and development of biofilms in the subsurface environment will depend on the presence of the microbes themselves; plus the availability of nutrients, energy sources and water necessary for life processes (West \& Chilton 1997). In a very low nutrient/energy environment with low groundwater flow, biofilms may not form and organisms may be dormant or maintain a very low metabolic rate. In this situation, it is unlikely that biofilm formation will influence the transport properties of the surrounding rock. However, in environments where nutrients and energy are more available, and where groundwater flow may be higher, biofilm formation will take place. As a result, the transport properties of the host rock will be altered to a greater or lesser degree depending on the characteristics and thickness of the biofilm and the nature of the rock itself. Such alteration in rock transport properties will be important to contaminant movement, as illustrated by some recent studies.

\section{Microbial transport studies associated with the Äspö Hard Rock Laboratory, Sweden}

The Äspö Underground Research Laboratory (URL) has been used for many studies and experiments evaluating aspects of the geological disposal of radioactive waste in hard rock (granodiorite) environments (SKB, Annual Reports 2003, 2004). The significance of microbiological processes in the containment of radioactive waste has long been recognised (West et al. 1982; West 1995, West \& McKinley 2002) and, consequently, detailed evaluations of the biofilms present on the walls of the URL and 
on the significance of indigenous microbial populations has been a key area of work (see Pedersen 1999 and references therein).

A recent in-situ study at the URL examined the redox buffering of groundwater in vertical fractures zones penetrated by recent, oxidising, shallow-recharged meteoric water, simulating processes that might occur in repository construction, and which could alter the geochemical experiment. This showed that indigenous bacteria were capable of maintaining reducing conditions in the deep groundwaters (Banwart 1995). As a result, a further laboratory experimental study was undertaken to simulate the interactions of microbes with mineralogical surfaces associated with groundwater flow systems at Äspö (Hama et al. 2001). Indigenous iron-reducing bacteria and sulphate-reducing bacteria were introduced in Äspö groundwater flowing through either columns or continuously stirred tank reactors (CSTR) packed with crushed Äspö diorite rock. The columns containing the organisms became blocked within a few days and no flow was possible. Petrographic analyses of the column residues inoculated with the bacteria indicated that the reduction in permeability in the columns was associated with (1) mobilisation of 'fines' from grain surfaces and their accumulation in intergranular pore throats (Plate 2); (2) development of filamentous organic biofilaments (Plate 3); and (3) formation of secondary mixed-layer chloritesmectite. The observed change in permeability, in the biotic experiments, was surprising because of the low concentration of available nutrients $(\mathrm{C}, \mathrm{S}, \mathrm{N}, \mathrm{P})$ and because any mineralogical changes involved (and hence changes in porosity) were volumetrically small. Although only a small amount of biofilament was produced, it formed a filamentous mesh that acted as a sieve, trapping any 'fines' migrating within pore throats, and also significantly decreased pore throat size whilst simultaneously increasing pore tortuosity. The liberation of 'fines' was not observed in the abiotic experiment and their appearance seemed to be related to the presence of the bacteria possibly influenced by surfactant properties of biocrobial exudates. The formation of the secondary chlorite-smectite during the biotic experiment may have also had an influence and this again appeared to be related to the presence of the organisms. The same formation of secondary clay was also observed in the 3 month long CSTR experiments although smectite, rather than the mixed-layer chlorite-smectite, was detected. Once again, the amount of smectite formed was greater in the biotic CSTR experiments demonstrating that the bacteria were having a significant influence on clay mineral formation in the experiments. More details of these studies are described elsewhere (West et al. 1998; Hama et al. 2001).

Other studies at the Äspö URL examined radionuclide sorption processes which compared the adsorption capacity of granitic rock to biofilms grown in situ on glass and rock surfaces (Anderson et al. 2006). After immersing the surfaces for 42 days in anaerobic synthetic groundwater containing a number of radioactive tracers the adsorption and distribution of the radionuclides was investigated using 2D autoradiography. Results showed that the rock absorbed more ${ }^{60} \mathrm{Co},{ }^{99} \mathrm{Mo},{ }^{241} \mathrm{Am}$, ${ }^{237} \mathrm{~Np}$ and ${ }^{234} \mathrm{Th}$ per unit area when compared to the biofilm grown on the glass slides whilst the biofilm absorbed more ${ }^{147} \mathrm{Pm}$ than the rock. Biofilms can form a barrier between the rock and groundwater and may slow down radionuclide diffusion to the rock. These results suggested that differences in adsorption were dependant upon the chemical properties of the individual radionuclides and the availability of different surface functional groups modified by the presence or absence of biofilms. 
Further experiments by Tuck et al (2006) used packed columns and stirred batch reactors to simulate microbial-geochemical interactions in deep subsurface low nutrient granitic environments. The columns, containing crushed Äspö grandodiorite and a single or mixed culture of chomolithotrophic bacteria became impermeable to synthetic Äspö groundwater after 5 days. Analysis revealed copious filamentous biofilm, encrusted with finer-grained material, across pore spaces with limited attachment sites on large grains in those columns. The work also suggested that the indigenous bacteria were capable of surviving in relatively low nutrient conditions and that bacteria can either concentrate relevant chemical species for mineral formation in localised microenvironments or may accelerate clay formation. This study implies that the localised hydrological regime of a granitic environment can be changed, particularly if new nutrient sources are introduced e.g. via links to surface water; or via links to the repository components. Biogenic mineral precipitates and trapped mineral matter are much more chemically and physically stable than the biofilm, and can persist in the pore system long after the biofilm has decayed or been removed (Brydie et al. 2005).

Studies by Ferris et al. (1999) with iron oxides and groundwater samples collected from the Äspö site looked at the extent to which dissolved metals sorbed into bacteriogenic iron oxides in a deep, hard rock groundwater environment. Results of metal distribution coefficients ( $\mathrm{K}_{d}$ values) showed $\mathrm{K}_{d}$ values decreased with increasing iron oxide content which appeared to be influenced by the bacterial organic matter in the solids. This has implications for the transport and fate of dissolved metals in groundwater systems where there is contact between iron oxides and bacterial organic matter.

Work by West et al. (1991) looked at radionuclide sorption onto a host rock, calcium montmorillonite (Fuller's Earth) as an important retarding mechanism. These studies used a batch sorption method (West et al. 1986) of groundwater spiked with ${ }^{137} \mathrm{Cs}$ and pure rock and microorganisms under a variety of conditions. In anaerobic conditions Cs and microbes were sorbed onto the rock material. A reduction in Cs was observed suggesting that the varying amounts of biofilm produced were able to bind metals from solution thus lowering the amount of Cs in the groundwater. Their results showed that the presence of microbes decreased the amount of retardation of ${ }^{137} \mathrm{Cs}$ by the solid phase.

Experiments to better understand the physicochemical processes occurring at the biofilm-mineral interface were designed by Vaughan et al. (2001). These experiments used miniature flow cells to grow single species biofilms within a simulated rock fracture environment. The structure of the resulting biofilms and the bacterial distribution was determined using confocal scanning laser microscopy. Results indicated a greater permeability of the biofilm in the centre compared to the surrounding matrix areas surrounding it. This suggested that biofilms might have the effect of producing localised flow gradients and may have an important impact on hydraulic properties when modelling a flowing system.

Experiments have shown that fluid movement is influenced by the presence of microorganisms in the system, in particular the presence of biofilms. Where conditions are suitable there is potential for biofilaments to establish (in a matter of 
days) causing pore blockages resulting in a decrease in permeability of the porous media and a change in the local fluid flow patterns. Extensive formation of biofilm reduces pore space, which can lead to eventual blocking of the pore system (Taylor and Jaffé 1990a;b; Taylor et al. 1990) referred to as 'bioclogging' (Brydie et al. 2005). Brydie et al. (2005) observed a $70 \%$ reduction in the permeability of sand due to bioclogging. Even greater permeability reductions (three orders of magnitude) were observed in earlier studies by Taylor and Jaffé (1990a).

\section{Modelling of biofilms}

There have been numerous attempts to model microbial growth in sub-surface environments and its effects on contaminant transport in groundwater. These models may be grouped into a number of categories depending upon sophistication and the nature of the processes that they try to represent: 'microbe mass balance' models, 'coupled microbe growth and mass transport' models and 'microbial transport and clogging' models.

The microbe mass balance model is perhaps the simplest in concept since it just attempts to calculate the limits to growth from the available supplies of nutrients and energy provided by the flow of groundwater and the leaching of the solid phase. This style of model was first proposed by Grogan and McKinley (1990) and similar models were used by Baker et al. (1998) and Jolley et al. (2003)

There are numerous models of 'coupled microbe growth and mass transport' reported in the literature over the past 30 or more years. A review of these models by Baveye and Valocchi (1989) divided them into three groups according to the treatment of the attached bacteria. The first group (I) consisted of those models that neglected pore scale processes and assumed that the bacteria respond directly to the macroscopic bulk fluid composition. The other two groups were based upon the assumptions of the bacteria forming microcolonies (II) or biofilms (III). Examples of the first group of models may be found in Corapcioglu and Haridas (1984), Corapcioglu and Haridas (1985), and Kindred and Celia (1989). Examples of the microcolonies approach are found in Molz et al. (1986) and Widdowson et al. (1988) whilst the biofilm approach was used, for example, in Rittmann et al. (1980) and Bouwer and McCarty (1984). Baveye and Valocchi noted the formal similarities in all the mathematical models with the differences arising in the detailed implementation of particular terms.

Widdowson (1991), in commenting on this review, noted the particularly close association of model types I and II, but demonstrated that the differences in detail could result in noticeable differences in the calculated concentrations. Widdowson also questioned the applicability of the biofilm concept to subsurface environments.

Microbial transport and clogging models are really a sub-set of those described in the previous section. They are distinguished by the fact that they attempt to model the changes in the hydraulic properties of the medium as well as the microbial growth and consequent changes of porewater chemistry. Examples of such models may be found in Corapcioglu and Haridas (1984), Corapcioglu and Haridas (1985), Vandevivere et al. (1995), Clement et al. (1996), and Thullner et al. (2004). 


\section{Discussion}

These studies show the biofilm formation can have a significant impact on the porosity and permeability of fractures and porous media. These are illustrated in Figure 1(a) and can be summarised as:

1. Direct effects, including: (reduction of fluid flow by constriction of pore throats and increasing the tortuosity of the pore network flow paths; sorption of contaminants onto biofilm; uptake of contaminants onto mobile and motile microbes).

2. Indirect effects, including: (biofilm/groundwater interaction with $\mathrm{pH}$; redox changes; alteration of groundwater chemistry; rock/biofilm interaction with $\mathrm{pH}$, redox changes, alteration of rock surface; biomineralisation).

Figure 1(b) summarises how a pore or fracture flow path is blocked by the growth of biofilm filaments 'capturing' mineral particles which effectively stops fluid movement. Figure 1(c) shows the effect of high fluid flow on biofilm removal from a surface which, in effect, indicates the shearing off of a large section of biofilm which would then be transported until it lodges and potentially blocks another flow path. This can be viewed as analogous to what occurs in the coronary heart disease, where fatty deposits on blood vessel walls slow down blood flow and can potentially shear off and lodge in other narrowed blood vessels (http://www.bhf.org.uk/default.aspx access date 16 May 2007).

The direct effect of the accumulation of microbial biomass and EPS is to reduce pore spaces in porous media which can lead to eventual blocking of the pore system (Taylor and Jaffé 1990a \& b; Taylor et al. 1990). Biofilms may further reduce permeability by acting as a filter, trapping fine-grained mineral particles and colloidal material moving through the pore system and increasing pore tortuosity (Hama 1997). In addition, microbially-mediated mineral precipitation can result in plugging or cementing of pore space thus further reducing porosity and permeability. Experimental studies have shown that even in groundwater systems with a low nutrient supply, small amounts of biofilm can form that trap particulate material and effectively prevent fluid flow after a few hours (West et al. 1998; Hama et al. 2001). Such biogenic mineral precipitates and trapped mineral matter has a much higher chemical and physical stability than the biofilm, and therefore can persist in the pore system long after the biofilm has decayed or been removed (Brydie et al. 2005). The phenomenon of pore clogging is a well known problem in soil science, water treatment and the petroleum industry (Taylor \& Jaffé 1990a). In the oil industry, the attempt to improve oil recovery by injecting water into hydrocarbon reservoirs is often accompanied by the accumulation of biofilms resulting in clogging and formation damage near the injection well.

Even the development of smallest amounts of biofilm can alter transport properties of porous media systems significantly. As many biofilms are filamentous or bridge across pores (West et al. 1998; Hama et al. 2001; Brydie et al. 2005) they narrow or divide pore spaces into smaller pores separated by biofilm. Both reduced pore throat size and increased flow-path tortuosity result in a dramatic decrease in permeability. This effect is analogous to the significant reduction of permeability observed in 
sandstone reservoirs and aquifers, associated with the growth of very small amounts of authigenic fibrous illite clay (Milodowski et al. 1987).

The formation of biofilms can also affect flow velocity in its immediate vicinity. Previous studies showed that the presence of biofilms has influence on hydrodynamics and may increase or decrease the frictional resistance, depending on the degree of biofilm accumulation. In experiments using a flat plate reactor with and without biofilm (Lewandowski et al. 1992) a considerable difference in flow velocity was noticed. The plate reactor without biofilm developed a jet form indicating flow instability; on the other side in the presence of the biofilm a viscous flow was fully developed. These observations resulted in the conclusion that the biofilm must have smoothed the surface in order to allow a more stable flow in the presence of the biofilm than in its absence. These experimental results differ from the popular opinion that biofilm formation increases the surface roughness in conduits. However, little is still known about these factors and recent studies seem to demonstrate that processes are much more complex then originally assumed. A study by Stoodley et al. (2002) into deformation and detachment of biofilm structures suggested that biofilms grown under higher fluid shear formed filamentous streamers, were more strongly adhered and had a stronger EPS matrix than those grown under lower fluid shear conditions.

The diffusion of radionuclides between fractures and rock matrix strongly influences the persistence of groundwater contamination in fractured rocks. Pathways within these fractures make it easy for contaminants to migrate, allowing solutes and colloidal particles (e.g. bacteria) to travel long distances in short periods of time in certain hydrogeological conditions. In this environment the presence of biofilms can have a significant effect on the solute transport properties of the matrix, and thus the mobility of contaminants within the system (Neretnieks 1980).

The development, morphology and physical stability of biofilms is influenced by several factors such as hydrodynamic and chemical conditions, nature of the substrate and nutrition supply. Changes in fluid chemistry can destabilise the biofilm, causing it to break up. High flow rates can apply shear on the biofilm, also causing it to break up (Taylor \& Jaffé 1990c; Brydie et al. 2005). Both of these processes could result in the mobilisation of microbial material through the pore system and consequently cause clogging elsewhere in the system. In a study by Leon-Morales et al. (2004), quartz sand-filled columns and quartz sand-packed microscope flow cells were used to investigate the influence of ionic strength on stability and mobility of the clay colloid laponite and a biofilm forming bacterium Pseudomonas aeruginosa. Experiments showed that in clean bed columns the mobility of laponite was strongly affected by ionic strength. The introduction of $\mathrm{NaCl}$ at concentrations of $1 \times 10^{-2} \mathrm{M}$ resulted in almost complete retention of laponite within the sand columns. The mobility of Pseudomonas aeruginosa was reduced by $\mathrm{NaCl}$ concentrations of up to $1 \mathrm{M}$ but the effect was not as pronounced as for laponite. At relatively high ionic strengths $\left(7 \times 10^{-2} \mathrm{M}\right)$, the introduction of laponite into a sand column containing a biofilm caused clogging and enhanced shear stress and thus laponite retention and remobilisation of a portion of the attached cells. By contrast in low ionic strength solutions $\left(6.2 \times 10^{-4} \mathrm{M}\right)$ detachment of biofilm cells and an altered laponite elution profile was observed. Further experiments using different types of cations showed that divalent cations can have a strong stabilizing effect on biofilms also increasing the retention of colloids. Environmental influences (e.g. intense rain events) can have 
major impact on ionic strength and/or the type of ions present and therefore are able to dramatically change the mobility of colloids and thus of pollutants near the surface.

\section{Summary}

Biofilm formation in the subsurface environment can have significant impact on the porosity and permeability of fractures and porous media. Experimental work has also shown the complexity of the biological/geochemical/physical processes involved in transport processes. This paper has discussed the results of a number of studies on the effects of biofilms on contaminant transport and fracture systems. The literature showed there has been some valuable work undertaken in this field but more data are required from experimental studies to provide quantitative data necessary for the development of biofilm models. In particular the effects of biofilms on contaminant and radionuclide transport under varying physical and chemical conditions are of major interest. This concurs with tighter legal regulations for radioactive and contaminant waste disposal and implies that more studies are necessary for a better understanding of microbial influenced processes beneath the surface. A current study ('Biotran') carried out by the British Geological Survey is looking into the effects of biofilm growth on transport processes under varying conditions $(\mathrm{pH}$, ionic strength, phage input). However, this is only the experimental beginnings of an area which is still little understood.

\section{Acknowledgements}

This paper is published with permission of the Executive Director of the British Geological Survey (NERC).

\section{References}

Anderson, C., Pedersen, K., Jakobsson, A. M. 2006. Autoradiographic comparisons of radionuclide adsorption between subsurface anaerobic biofilms and granitic host rocks. Geomicrobiology Journal 23, 15-19.

Baker, S J, West, J M, Metcalfe, R, Noy, D J, Yoshida, H, and Aoki, K. 1998. A biogeochemical assessment of the Tono site, Japan. Journal of Contaminant Hydrology 35, 331-340.

Banwart, S. 1995. The Äspö redox investigations in block scale project summary and implications for repository assessment. Swedish Nuclear Fuel and Waste Management Co., Stockholm, Sweden. SKB Technical Report, 95-26.

Baveye, P, \& Valocchi, A J. 1989. An evaluation of mathematical models of the transport of biologically reacting solutes in saturated soils and aquifers. Water Resources Research 25(6), 1413-1421. 
Beveridge, T. J., Makin, S. A.. Kadurugamuwa, J. L. \& Li, Z. 1997 Interactions between biofilms and the environment. FEMS Microbiology Reviews 20, 291-303.

Beyenal, H., Donovan, C., Lewandowski, Z., Harkin, G. 2004. Three-dimensional biofilm structure quantification. Journal Microbioogical. Methods 59, 395-413.

Bishop, P.L., Tian, C.Z., Yun-Chang, F. 1995. Effects of biofilm structure, microbial distributions and mass transport on biodegradation processes. Water Science and Technology 31, 143-152.

Bouwer, E J, and McCarty, P L. 1984. Modelling of trace organics biotransformation in the subsurface. Ground Water 22, 433-440.

Brydie, J.R., Wogelius, R.A., Merrifield, C.M., Boult, S., Gilbert, P., Allison, D., Vaughan, D.J. 2005. The $\mu 2 \mathrm{M}$ project on quantifying the effects of biofilm growth on hydraulic properties of natural porous media and on sorption equilibria: an overview. In: Shaw, R.A. (Editor). Understanding the micro to macro behaviour of rock-fluid systems. Geological Society, London. Special Publication 249, 131-144.

Chapelle, F.H. 2000. In: Ground-water microbiology and geochemistry: New York, John Wiley and Sons, 468 p.

Clement, T P, Hooker, B S, and Skeen, R S. 1996. Macroscopic models for predicting changes in saturated porous media properties caused by microbial growth. Ground Water 34(5), 934-942.

Corapcioglu, M Y, \& Haridas, A. 1984. Transport and fate of microorganisms in porous media: A theoretical investigation. Journal of Hydrology 72, 142-169.

Corapcioglu, M Y, \& Haridas, A. 1985. Microbial transport in soils and groundwater: A numerical model. Advances in Water Resources 8, 188-200.

Cunningham, A. L., Warwood, B., Sturman, P., Horrigan, K., James, G., Costerton, J. W. \& Hiebert, R. 1997. Biofilm processes in porous media - practical applications. In: Amy, P.A., Haldeman, D. L. (eds), The Microbiology of the Terrestrial Deep Subsurface. CRC Lews Publishers, pp 325-344.

Dornieden, T., Gorbushina, A. A., \& Krumbein, W. E. 2000. Biodecay of cultural heritage as a space/time-related ecological situation - an evaluation of a series of studies. International Biodeterioration and Biodegradation 46, 261-270.

Dowd, S. E., Herman, D.C., Maier, R.M. 2000. Aquatic and Extreme Environments. In:.R.M. Maier., I.L. Pepper, \& C.P. Gerba (eds) Environmental Microbiology, Academic Press, London. 123-146.

Ehrlich, H. L. 1999. Microbes as geologic agents:their role in mineral formation. Geomicrobiology Journa. 16, 135-153. 
Ferris, F.G., Konhauser, K.O., Lyvén, B. \& Pedersen, K. 1999. Accumulation of metals by bacteriogenic iron oxides in a subterranean environment. Geomicrobiology Journal, 16, 181-192.

Fletcher, M. 1991. The physiological activity of bacteria attached to solid surfaces. Advances in Microbiological Physiology 32, 53-85.

Frederickson, J.K., Garland, T. R., Hicks. R. J., Thomas, J. M., Li, S. W., \& McFadden, K. M. 1989. Lithotrophic and heterotrophic bacteria in deep subsurface sediments and their relation to sediment properties. Geomicrobiology Journal 7, 5366.

Grogan, H A, and McKinley, I G. 1990. An approach to microbiological modelling: application to the near field of a Swiss low/intermediate-level waste repository. NAGRA technical report 89-06.

Hama, K., Bateman, K., Coombs, P. Hards, V.L., Milodowski, A.E., West, J.M., Wetton, P.D., Yoshida, H., Aoki, K., 2001. Influence of bacteria on rock-water interaction and clay mineral formation in subsurface granitic environments. Clay Minerals 36, 599-613.

Hama, T. 1997. Primary productivity and photosynthetic products in the Northwest Pacific Ocean. In: Biochemical Processes in the North Pacific, Proceedings of the International Marine Science Symposium, 187-191.

Jolley, D M, Ehrhorn, T F, and Horn, J. 2003. Microbial impacts to the near-field environment geochemistry: a model for estimating microbial communities in repository drifts at Yucca Mountain. Journal of Contaminant Hydrology 62-63, 553575.

Keith-Roach, M. J. and Livens, F. R. (eds) 2002. Interactions of microorganisms with radionuclides. Elsevier, Oxford, UK. 400pp.

Konhauser, K. O., Fisher, Q. J., Fyfe, W.S., Longstaff, F. J. \& Powell, M. A. 1998 Authigenic mineralisation and detrital clay binding by freshwater biofilms: The Brahmani River, India. Geomicrobiology Journal 15, 209-222.

Kindred, J S, and Celia, M A. 1989. Contaminant transport and biodegradation. 2. Conceptual model and test simulations. Water Resources Research 25(6), 1149-1159.

Leon-Morales, C.F., Leis, A.P., Strathmann, M., Flemming, H.-C. 2004. Interactions between laponite and microbial biofilms in porous media: implications for colloid transport and biofilm stability. Water Research 38, 3614-3626.

Lewandowski, Z., Altobelli, S.A., Majors, P.D., Fukushima, E. 1992. NMR imaging of hydrodynamics near microbially colonized surfaces. Water Science and Technology 26(3/4), 577-584.

Marsh, P. D. 2004. Dental plaque as a microbial biofilm. Caries Research 38, 204211. 
Milodowski, A.E., Strong, G.E., Wilson, K.S., Holloway, S., Bath, A.H. 1987. Diagenetic influences on the aquifer properties of the Permo-Triassic sandstones in the East Yorkshire and Lincolnshire basin. Investigation of the Geothermal Potential of the UK, British Geological Survey, 36 pp

Milodowski. A. E., West, J. M., Pearce, J. M., Hyslop, E. K., Basham, I. R. \& Hooker, P. J. 1990. Uranium-mineralised microorganisms associated with uraniferous hydrocarbons in southwest Scotland. Nature 347, 465-467.

Molz, F J, Widdowson, M A, Benefield, L D. 1986. Simulation of microbial growth dynamics coupled to nutrient and oxygen transport in porous media. Water Resources Research 22(8), 1207-1216.

Neretnieks, I. 1980. Diffusion in the rock matrix: an important factor in radio nuclide retardation? Journal of Geophysical Research 85, 4379-4397.

Okabe, S., Kuroda, H., Watanabe, Y. 1998. Significance of biofilm structure on transport of inert participates into biofilms. Water Science and Technology 38, (8), 163-170.

Paulsen, J.E., Oppen, E., Bakke, R. 1997. Biofilm morphology in porous media, a study with microscopic and image techniques. Water Science and Technology 36, 1-9.

Pedersen, K. 1999. Subterranean microorganisms and radioactive waste disposal in Sweden. Engineering Geology 52, 163-172.

Rittmann, B E., McCarty, P L, \& Roberts, P V. 1980. Trace-organic biodegradation in aquifer recharge. Ground Water 18, 236-243.

SKB, 2003. Äspö hard rock laboratory. Annual Report 2002. Swedish Nuclear Waste and Fuel Management Company (SKB). Technical Report TR-03-10.

SKB, 2004. RD \& D - Programme 2004. Swedish Nuclear Waste and Fuel Management Company (SKB). Technical Report TR-04-21.

Stoodley, P., Cargo, R., Rupp, C.J., Wilson, S \& Klapper, I. 2002. Biofilm material properties as related to shear-induced deformation and detachment phenomena. Journal of Industrial Microbiology and Biotechnology 29, 361-367.

Taylor, S.W., Jaffé, P.R. 1990a. Biofilm growth and related changes in the physical properties of a porous medium. 1. Experimental investigation. Water Resources Research 26, 2153-2159.

Taylor, S.W., Jaffé, P.R. 1990b. Biofilm growth and related changes in the physical properties of a porous medium. 3. Diversity and model verification. Water Resources Research 26, 2171-2180.

Taylor, S.W., Jaffé, P.R. 1990c. Substrate and biomass transport in a porous medium. Water Resources Research 26, 2181. 
Taylor, S.W., Milly, P.C.D \& Jaffé, P.R, 1990. Biofilm growth and related changes in the physical properties of a porous medium. 2. Permeability. Water Resources Research 26, 2161-2169.

Thullner, M, Schroth, M H, Zeyer, J, and Kinzelbach, W. 2004. Modeling of a microbial growth experiment with bioclogging in a two-dimensional saturated porous media flow field. Journal of Contaminant Hydrology 70: 37-62.

Tuck, V. A., Edyvean, R. G.J., West, J. M., Bateman, K., Coombs, P., Milodowski, A. E. \& McKervey, J. A. 2006. Biologically induced clay formation in subsurface granitic environments. J. Geochemical Exploration 90, 123-133.

Vandevivere, P, Baveye, P, De Lozada, D S, and DeLeo, P. 1995. Microbial clogging of saturated soils and aquifer materials: Evaluation of mathemetical models. Water Resources Research 31(9), 2173-2180.

Vaughan, D.J., Wogelius, R., Boult S. \& Merrifield, C. 2001. Quantifying the effects of biofilm growth on hydraulic properties and on sorbtion equilibria; microscopic to macroscopic measurements. Progress summary 02/01 - 11/01 Williamson Research Centre, University of Manchester

West, J. M., McKinley, I. G. \& Chapman, N. A. 1982. Microbes in deep geological systems and their possible influence on radioactive waste disposal. In:Radioactive Waste Management and the Nuclear Fuel Cycle 3, 1-15

West, J.M., Abbott, M.A.W. \& Rowe E.J. 1986. Microbial activity in nutrient depleted materials. Report of British Geological Survey Fluid Processes Research Group FLPU 86-8

West, J.M., Haigh, D.G., Hooker, P.J. \& Rowe, E.J. 1991. Microbial influence on the sorption of ${ }^{137} \mathrm{Cs}$ onto materials relevant to the geological disposal of radioactive waste. Experimentia 47, Birkhauser Verlag, CH-4010 Basel/Switzerland.

West, J. M., 1995. A review of progress in the geomicrobiology of radioactive waste disposal. Radioactive Waste Management and Environmental Restoration 19, 263283.

West, J. M. and Chilton, P. J., 1997. Aquifers as environments for microbiological activity. Quarterly Journal of Engineering Geology 30, 147-154.

West, J.M., Aoki, K., Baker, S.J., Bateman, K., Coombs, P., Gillespie, M.R., Henney, P.J., Reeder, S., Milodowski, A.E., Yoshida, H. 1998. Redox experiment in detailed scale (REX) - Complementary laboratory work to examine microbial effects on redox. Report SKB-PR-HRL-98-14, Swedish Nuclear Fuel and Waste Management Co., Stockholm, Sweden. Also published as report WE/97/3C, British Geological Survey, Keyworth, Nottingham. 
West, J. M. \& McKinley, I. G. 2002. The geomicrobiology of radioactive waste disposal. In: Bitton, G. (ed) The Encyclopaedia of Environmental Microbiology. John Wiley, New York.

West, J.M., Bateman, K., Coombs, P., Harrison, P., Milodowski, A.E., Noy, D., Vane, C.H., Wagner, D. 2006. Microbial transport and microbial indicators of mass transport through geological media - A literature survey. British Geological Survey, Keyworth, Nottingham. Internal Report IR/06/029.

Widdowson, M A, Molz, F J, and Benefield, L D. 1988. A numerical transport model for Oxygen and Nitrate based respiration linked to substrate and nutrient availability in porous media. Water Resources Research 24(9), 1553-1565.

Widdowson, M A. 1991. Comment on "An evaluation of mathematical models of the transport of biologically reacting solutes in saturated soils and aquifers." by Phillipe Baveye and Albert Valocchi. Water Resources Research 27(6), 1375-1378.

Wimpenny, J., Manz, W., Szewzyk, U. 2000. Heterogeneity in biofilms. FEMS Microbiology Reviews 24, 661-671

Plate 1 Biofilm formation on the surface of a disused mine wall in Derbyshire, UK

Plate 2 CryoSEM photomicrograph showing fine-grained secondary smectite-like phase precipated as a pore-bridging clay and blocking a pore throat

Plate 3 SEM photomicrograph showing a meshwork of organic filaments trapping fine-grained mineral particular matter

Figure 1. (a) The effect of biofilm formation on the porosity and permeability of a fracture/fissure flow environment. (b) How a pore or fracture flow path is blocked by the growth of biofilm filaments 'capturing' mineral particles which effectively stops fluid movement. (c) The effect of high fluid flow on biofilm removal from a surface showing the shearing off of a large section of biofilm which would then be transported until it lodges and potentially blocks another flow path. 
